\title{
Kajian Potensi Pengembangan Mangrove di Pesisir Puger Kabupaten Jember, Jawa Timur, Indonesia
}

\author{
Anita Dewi Moelyaningrum Ellyke ${ }^{\star *}$, Rahayu S Pujiati ${ }^{* *}$, Khoiron$^{* *}$ \\ * Fakultas kesehatan Masyarakat. Institute for Maritime Studies (IMaS) Universitas Jember, \\ ** Fakultas Kesehatan Masyarakat. Universitas Jember, Jawa Timur Indonesia. \\ JL. Kalimantan 1 No.93 Jember. Jawa Timur. \\ Email: anitamoelyani@gmail.com or anitadm@unej.co.id;
}

\begin{abstract}
ABSTRAK
Hutan mangrove memilik banyak manfaat, baik bagi perekonomian masyarakat maupun sebagai pelindung kawasan pantai, termasuk juga dipesisir pantai puger. Tujuan kajian ini adalah mengidentifikasi tangggapan masyarakat terhadap pengembangan mangrove baik lingkungan, ekonomi, persepsi, perilaku, tingkat partisipasi dan permasalahan serta pemecahan masalah yang bisa dilakukan di masyarakat. Kajian ini dilakukan di kelurahan puger wetan kabupaten Jember. Metode mendapatkan data adalah dengan wawancara mendalam dan terstruktur dan observasi pada warga sekitar sebanyak 30 responden. Hasil kajian ini menunjukkan bahwa karakteristik respondon sebagian besar usia 40-49 tahun, tamatan Sekolah dasar, pendapatan sekitar 1-1,5 juta. Dari segi lingkungan, Masyarakat beranggapan bahwa mangrove mampu melindungi pesisis dari ombak, sebagai tempat berlindung untuk ikan, udang, ketam. Dari segi ekonomi masyarakat beranggapan dapat meningkatkan jumlah tangkapan ikan. Dari segi perilaku, masyarakat tidak pernah memanfaatkan mangrove secara langsung terutama untuk menunjang perekonomian mereka. Namun demikian keinginan untuk berpartisipasi dalam pengembangan mangrove didaerah mereka cukup tinggi. Kendala yang dijumpai adalah adanya kepercayaan bahwa kapal jika tidak melaut tidak boleh terkena air laut, sehingga masyarakat menebang mangrove untuk tempat pendataran kapal, banyak sampah dan tidak memiliki akses bibit mangrove. Untuk itu perlu adanya pengaturan tempat pendataran perahu, pembagian daerah konservasi dan pengelolaan sampah terpadu di masyarakat oleh pemerintah terkait supaya pengembangan potensi mangrove dapat optimal.
\end{abstract}

Kata Kunci : Potensi Mangrove, pesisir, lingkungan, ekonomi, sosial.

\section{PENDAHULUAN}

Indonesia merupakan negara kepulauan dan memiliki garis pantai nomor dua terpanjang di dunia setelah kanada, yaitu lebih dari $81.000 \mathrm{~km}$. Secara fisik Indonesia merupakan negara kepulauan terbesar di dunia, dengan luas laut sekitar 3,1 juta km2 atau 62\% dari luas teritorialnya (Dahuri et al., 2002) 
Kabupaten Jember Propinsi Jawa timur dikenal luas akan pantainya. Kecamatan Puger merupakan wilayah pesisir yang menghasilkan banyak hasil laut sebagai sumber perekonomian warga sekitar. Kecamatan Puger mempunyai luas wilayah $149.00 \mathrm{Km}^{2}$ dengan ketinggian rata-rata 12 $\mathrm{m}$ dari atas permukaan laut.

Mangrove atau di Indonesia biasa disebut bakau adalah sekelompok tumbuhan dri marga Rhizopora, suku Rhizophoraceae. Tumbuhan ini memiliki ciri-ciri yang mencolok, yaitu berupa akar tunjang yang besar dan berkayu, pucuk yang tertutup daun penumpu yang meruncing, serta buah yang berkecambah serta berakar ketika masih di pohon (vivipar). Di lingkungan atau habitat yang sesuai, mangrove bisa tumbuh lebat dan membentuk hutan. Hutan mangrove ini biasanya tumbuh diatas rawa-rawaberair payau yang terletak pada garis pantai dan dipengaruhi oleh pasang surut air laut. Hutan ini tumbuh khususnya di tempat-tempat dimana terjadi pelumpuran dan akumulasi bahan organik. Baik di teluk-teluk yang terlindung dari gempuran ombak, maupun di sekitar muara sungai dimana air melambat dan mengendapkan lumpur yang dibawanya dari hulu.

Hutan mangrove memiliki kegunaan yang sangat banyak, baik bagi perekonomian masyarakat maupun sebagai pelindung kawasan panatai. Paling tidak ada 4 kegunaan hutan mangrove bagi perlindungan kawasan pantai, yaitu melindungi pesisir dari tekanan fisik seperti ombak yang mengikis pantai dan angin pantai yang kencang, menstabilkan kawasan pantai dan bertindak sebagai penahan kalau terjadi angin topan, menjadi tempat perlindunga beberapa spesies flora dan fauna yang biasa hidup di lingkungan mangrove (banyak spesies udang marin dan ikan mencari makanan, bertelur dan tumbuh besar disini), dan mengurangi kesan ombak tsunami di sepanjang pinggir pantai.

Sementara kegunaan hutan mangrove bagi perekonomian masyarakat yaitu bisa sebagai bahan bangunan, kayu bakar, dan terutama sebagai bahan pembuat arang. Kulit kayu menghasilkan tanin yang digunakan sebagai bahan penyamak, atau lebih detil lagi dari kegunaan hutan mangrove bagi perekonomian yaitu: Pertama, banyak spesies ikan, udang, dan ketam yang bernilai komersial hidup di kawasan mangrove dan sekitarnya. Keuntungan daripada kegiatan perikanan di kawasan mangrove mencapai milyaran rupiah setahun. Kedua. Kayu mangrove bisa dipakai untuk kayu baka, membuat rumah (sebagai rusuk dan tiang), membuat perangkap ikan, membuat arang serta bisa dipakai untuk membuat perabot rumah tangga (bakul dan tikar). Ketiga, tanin yang diperoleh dari kulit mangrove digunakan untuk mewarnai, kain layar, dan perekat plastik. Keempat, banyak bagian dari tumbuhan mangrove yang boleh dimakan dan semangnya dijadikan makanan oleh penduduk setempat. Kelima, sebagai obat-obatan, contohnya daun, tunas, buah, dan bijinya.

Namun begitu, penanaman mangrove tidaklah mudah. Ada beberapa syarat habitat atau lingkungan yang harus dipenuhi karena tidak semua jenis mangrove bisa tumbuh di lingkungan atau habitat yang sama. Ada mangrove yang sanggup hidup di tanah berlumpur, tetapi tidak sanggup di pantai yang berkarang. Atau ada mangrove yang sanggup kena hempas ombak yang besar, mangrove lainnya tidak sanggup hidup kalau terkena ombak besar. Oleh karena spesies mangrove tidak bisa hidup di setiap lingkungan atau habitat yang sama, maka perlu dilakukan kajian pemetaan pengembangan potensi mangrove di pesisir pantai Puger. 


\section{MATERI DAN METODE}

Metode penelitian ini adalah suatu pengkajian. Kajian ini dilakukan di kelurahan puger wetan kabupaten Jember. Merupakan penelitian deskriptif dengan pendekatan kualitatif yang melibatkan 30 informan. Informan dalam penelitian ini adalah nelayan yang menjadi anggota paguyupan nelayan di kelurahan puger wetan kabupaten jember sebanyak 30 orang nelayan yang masih aktif melaut. Data dikumpulkan dengan wawancara mendalam dan terstruktur dan observasi. Data dianalisa secara deskriptif tematik konten dengan penyajian tabel.

\section{Karakteristik responden}

\section{HASIL DAN PEMBAHASAN}

Usia. Dari 30 orang responden, sebagian besar terdapat berusia 40-49 tahun (33,3\%). kemudian umur 30-39 tahun sebanyak 9 orang (30\%), umur 50-59 sebanyak 5 orang (16,6\%), umur 20-29 tahun sebanyak 3 orang $(10 \%)$ dan umur $<20$ tahun sebanyak 1 orang $(3,3 \%)$. Menjalani profesi nelayan bagi sebagian besar penduduk puger wetan didapatkan secara turun temurun. Kedekatan tempat tinggal dengan daerah pantai menjadikan sebagian penduduk puger wetan sudah menjalani profesi sebagai nelayan sebagai sumber mata pencaharian. Hal ini terlihat dari sebaran usia responden nelayan yang bervariasi. Profesi sebagai nelayan membutuhkan kemampuan fisik yang prima. Usia memiliki keterkaitan yang erat dengan kemampuan fisik dan fisiologis seseorang dalam bekerja termasuk menjadi nelayan. Usia produktif adalah usia yang paling baik bagi seseorang untuk bekerja dari sisi fisiologi tubuh. Dari sebaran usia, sebagian besar responden masih dalam rentang usia produktif. Sebagaimana hasil penelitian pakpahan (2006) yang menyebutkan bahwa sebagian besar profesi nelayan dilakukan pada usia produktif.

Tingkat Pendidikan. Untuk tingkat pendidikan responden, Sebagian besar adalah tamatan sekolah dasar (SD) yaitu terdapat 11 responden (16,7\%). Kemudian diikuti dengan 9 orang tamatan SMP $(30 \%), 5$ orang tidak tamat SD $(16,7 \%)$ dan 1 orang tamatan SMA $(3,3 \%)$. Tingkat pendidikan responden masih tergolong rendah. Sesuai dengan hasil penelitian Prihandoko dkk (2012) yang menunjukkan bawa nelayan di pesisir utara jawa barat memiliki tingkat pendidikan formal dan non formal yang rendah. Tingkat pendidikan seseorang sering kali berkaitan dengan bagaimana seseorang menyerap informasi yang diterima. Informasi pengumpulan, penyimpanan, pemrosesan, penyebaran berita, data, Grafik, fakta dan pesan, opini dan komentar yang dibutuhkan agar orang dapat mengerti dan bereaksi secara jelas terhadap kondisi nasional, lingkungan dan orang lain dan agar dapat mengambil keputusan yang tepat (O. W. Effendi, $2006 ; 27$ )

Tingkat Pendapatan. Terdapat data jumlah penghasilan yang bervariasi pada responden. Dari hasil wawancara, diperoleh data bahwa sebagian besar responden memiliki pendapatan kurang lebih Rp. $500.000,00-<1000.000,00$ per bulan yaitu sebanyak 9 orang responden (30\%). Kemudian responden yang memiliki pendapatan antara Rp. 1000.000,00- $<1.500 .000,00$ sebanyak 8 orang 
$(26,65)$. Terdapat 5 orang responden (16,6\%) yang memiliki pendapatan antara Rp. 1.500.000,00$2000.000,00$ dan terdapat 4 orang responden (13,3\%) yang memiliki pendapatan antara Rp. $300.000,00-<500.000,0$ dan Rp. $>2000.000,00$ per bulan. Sebagian besar pendapatan nelayan di Indonesia termasuk rendah. Sebagaimana penelitian purwati ()

hasil penelitian ini menunjukkan bahwa Sebagian besar tingkat pendapatan responden nelayan puger wetan juga rendah. Rendahnya tingkat pendapatan nelayan disebabkan sebagian besar mereka hanya melaut jika kondisi alam dan kesehatan memungkinkan mereka untuk melaut. Jika kondisi tidak memungkinkan untuk melaut dan mendapatkan tangkapan ikan, nelayan tidak memiliki pendapatan karena tidak memiliki keterampilan lain.

\section{Tanggapan Terhadap Pengembangan Mangrove}

Pengembangan mangrove dipesisir puger akan berjalan optimal jika masyarakat memiliki tanggapan yang positif. Tanggapan adalah apa yang diterima oleh panca indra yang melahirkan pikiran, perasaan, pendapat pandangan dan reaksi (W.J.S. Poerwadarminta, 1979). Tanggapan masyarakat terkait keberadaan mangrove perlu di ukur supaya dapat diketahui bagaimana potensi pengembangan di pesisir puger. Tanggapan masyarakat merupakan sikap masyarakat untuk mengungkapkan apa yang dirasakan, menunjukkan rasa suka atau tidak suka terhadap suatu keadaan.

Tanggapan masyarakat terhadap keberadaan mangrove di sepanjang pesisir pantai puger diketahui dengan memberikan pertanyaan kepada responden apakah mereka setuju atau menerima terhadap keberadaan mangrove di sepanjang pesisir pantai puger. Dari 30 responden, ternyata terdapat 2 orang $(6,7 \%)$ yang tidak setuju. Namun terdapat 28 responden $(93,3 \%)$ yang setuju terhadap adanya pengembangan mangrove di pesisir puger. Data secara lengkap dapat dilihat pada tabel 1.

Tabel 1. Tanggapan Terhadap Pengembangan Mangrove
\begin{tabular}{|r|r|r|r|}
\hline No & Tanggapan & Jumlah & Prosentasi \\
\hline 1. & setuju & 28 & 93,3 \\
\hline 2. & Tidak setuju & 2 & 6,7 \\
\hline & Total & 30 & 100 \\
\hline
\end{tabular}

Tanggapan ini memberikan sinyal positif untuk dilakukan pengembangan mangrove di pesisir puger.

Dari jawaban setuju maupun jawaban tidak setuju responden, kemudian digali lebih lanjut alasan mengapa mereka setuju terhadap keberadaan mangrove. Beberapa alasan kesetujuan untuk dilakukan pengembangan kembali mangrove dipesisir puger antara lain karena dulu ketika masih banyak bakau atau mangrove bisa mengambil banyak udang maupun ikan dibawah akar mangrove. Sebagaimana pengakuan responden yaitu bapak Z (usia 55 tahun):

"Saya setuju mas kalau ada bakau, soalnya bisa menjaga kampung dari air pasang atau tsunami”. Pernyataan bapak Z ini juga didukung oleh Bapak I (42 tahun) yang mengatakan bahwa "kulo setuju mergo saget nahan ombak" 
Sedangkan alasan lain yang disampaikan responden adalah dengan banyaknya bakau atau mangrove maka akan mendatangkan ikan, udang dll. sebagaimana diungkapkan oleh bapak M (35 tahun):

"Kulo setuju, mergo saget damel omahe iwak".

Dengan banyaknya ikan yang ada disela akar bakau atau mangrove, maka sangat diharapkan dapat meningkatkan hasil tangkapan ikan nelayan. Hutan mangrove sendiri, merupakan ekosistem yang baik untuk pengembangbiakan ikan, dimana ikan akan cukup mendapatan plankton serta perlindungan yang baik ketika bertelur. Selain ikan ada beberapa spesies yang dapat hidup di hutan mangrove atau hutan bakau seperti kepiting, kerang, burung dll yang akan sangat bermanfaat bagi perekonomian masyarkat sekitar. Sebagaimana diungkapkan oleh responden yaitu bapak A (49 tahun) :

"setuju, ikane saget kathah, udang kathah".

Bapak F (50 thn) juga mengungkapkan bahwa dengan banyak akar (bakau) mengundang banyak ikan, sebagaimana pernyataan beliau "kalau bnyk akar (bakau), banyak ikan". Sedangkan alasan responden yang lain setuju karena dengan adanya mangrove atau bakau maka laut lebih terlihat indah dan hijau. Sebagaimana diungkapkan oleh bapak $\mathrm{R}$ (30 tahun): "saya setuju dengan adanya mangrove, supaya pantai puger kelihatan hijau"

Tanggapan positif masyarakat pesisir puger, menunjukkan bahwa potensi masyarakat mau turut serta dalam pengembangan mangrove didaerah mereka sangat besar. Sikap positif responden terhadap pengembangan mangrove merupakan modal awal dan utama dalam pengembanga mongrove di pesisir puger.

Walaupun demikian, terdapat 2 orang responden yang tidak setuju dengan keberadaan mangrove di pantai puger karena dianggap mengganggu perahu yang bersandar, dan mengatakan tidak ada tempat untuk penanaman mangrove di pantai puger. Alasan lain yaitu karena merasa bahwa kayu tanaman mangrove tidak bisa dimanfaatkan. Sebagai mana yang diungkapkan oleh bapak $\mathrm{U}$ (27 tahun) yang mengatakan bahwa :

"saya tida setuju, karena tidak ada tempat untuk menanam mangrove di sini",

sedangkan bapak D 9 (34 tahun ) mengungkapkan bahwa: "saya tidak setuju karena perahu saya tidak bisa sandar".

Masih adanya tanggapan negatif dari masyarakat pesisir puger wetan terkait pengembangan mangrove disebabkan oleh ketidaktahuan akan pentingnya keberadaan mangrove. Mangrove di anggap tidak memiliki nilai guna dan mengganggu perahu nelayan untuk bersandar.

\section{Tanggapan Masyarakat terhadap manfaat mangrove}

\section{Tanggapan Masyarakat terhadap Manfaat Mangrove di Bidang Lingkungan}

Dari tanggapan responden terhadap keberadaan mangrove, kemudian reponden ditanya lebih jauh tentang tanggapan terhadap manfaat mangrove terhadap lingkungan. Mangrove memiliki manfaat yang besar bagi manusia, lingkungan termasuk ekonomi. Mangrove mampu memberikan perlindungan dari badai dan erosi serta pendapatan langsung bagi masyarakat 
manusia melaui kegiatan wisata (Krauss, dkk. 2008; Martinuzzi dkk. 2009). Kerusakan lingkungan mangrove seringkali disebabkan oleh rendahnya tingkat pendidikan nelayan dan kurangnya pengetahuan dalam menjaga lingkungan (Primyastanto, 2010). .

Dari hasil jawaban responden, terlihat bahwa tanggapan masyarakat terhadap manfaat mangrove di bidang lingkungan cukup bervariasi. Sebagian besar responden setuju (96,7\%) bahwa Akar tanaman mangrove merupakan tempat berlindung dan berkembang biak untuk flora dan fauna, sehingga dengan adanya mangrove memungkinkan tangkapan ikan meningkat. Mangrove juga dianggap mampu melindungi pesisir dari ombak oleh responden (93,3\%). Namun demikian terdapat 3,3 \% responden yang mengatakan bahwa mangrove bukan merupakan tempat berlindung dan berkembang biak untuk flora dan fauna, dan juga masih terdapat 6,7\% responden yang berpendapat bahwa mangrove tidak dapat melindungi pesisir dari ombak. Sebagaimana yang disampaikan oleh bapak S (49 tahun) yang menyatakan bahwa:

"mangrove saget nahan ombak, akare beda kaliyan tumbuhan lain, kuat", "Mangrove akare bisa jadi tempat rumah ikan".

Sedangkan bapak R (51 tahun) juga mengatakan bahwa :

"Tanduran mangrove bisa dipakai berteduh ikan di akarnya".

Alasan lainnya yaitu ikan bisa makan disekitar akar mangrove, akarnya kuat.

Namun, Beberapa responden menjawab bahwa mangrove bukan tempat berlindung ikan, tidak bisa menahan ombak disebabkan responden tidak mengetahui jenis, bentuk maupun manfaat tanaman mangrove terhadap lingkungan.

Terdapat 79,3\% responen yang menyatakan bahwa tanaman mangrove dapat menahan abrasi atau masuknya air laut ke daratan atau pemukiman dan $86,7 \%$ responden menganggap tanaman mangrove dapat membuat stabil kawasan pantai. Beberapa alasan yang dikemukakan adalah akarnya yang kuat, letaknya di pinggir pantai, dapat menahan banjir air laut, penghijauan pantai dll sehingga tanaman mangrove dapat menahan abrasi serta dapat membuat stabil pantai. Terdapat $20,7 \%$ dan $13,3 \%$ responden yang menjawab bahwa tanaman mangrove dapat menahan abrasi dan menstabilkan pantai karena tidak tahu wujud tanaman mangrove. Sebagaimana pak K (29 tahun) yang mengatakan bahwa ombak masuk bukan karena ada atau tidaknya tanaman mangrove namun karena sebab lain. Pak K (29 tahun) mengatakan bahwa:

"ombak masuk sungai karena ada dangkalan dari sungai bedadung"

Dari 86,7 \% reponden berpendapat bahwa tanaman mangrove dapat melindungi pesisir dari bencana tsunami karena akarnya yang kuat sehingga tidak mudah terhempas ombak. Tetapi terdapat $13,3 \%$ responden yang mengatakan bahwa tanaman mangrove tidak dapat melindungi pesisir dari tsunami. Bapak S (48 tahun) mengatakan bahwa : 
"tsunami itu besar sekali mb..., ya tidak mungkin mangrove bisa melindungi dari tsunami"

Beberapa responden menganggap bahwa mangrove tidak dapat memberikan manfaat untuk menetralisir racun dari air sungai yang tercemar. Padahal dengan adanya mangrove laju cemaran air sugai dapat ditahan oleh akar mangrove, sehingga air yang masuk ke laut lebih bersih dan akan meningkatkan jumlah ikan tangkapan secara tidak langsung.

Bahwa ekosistem mangrove dapat berfungsi sebagai filter untuk menurunkan racun dari air sungai yang tercemar sebelum masuk ke laut disampaikan oleh 56,7 \% responden. Mereka beranggapan bahwa sampah dapat tersangkut pada akar tanaman mangrove, sehingga sampah tidak masuk laut, namun terdapat 43,3\% responden yangn tidak paham bahwa tanaman mangrove dapat menurunkan berbagai racun dari air sungai yang tercemar.

Terdapat responden beranggapan bahwa dengan adanya tanaman mangrove maka akan membuat populasi nyamuk semakin banyak. Dimana mereka beranggapan bahwa mangrove dapat menjadi tempat nyamuk karena banyak semak sehingga menjadi tempat sarang nyamuk. Bpk S (44 tahun) mengatakan bahwa :

"mangrove itu bisa membuat sarang nyamuk, jadi nyamuknya tambah banyak". Sebaagaimana pak D (32 tahun) mengatakan bahwa :

"Kalau ada mangrove, nyamuknya jadi banyak".

Namun demikian masih terdapat $40 \%$ responden yang sependapat bahwa tanaman mangrove dapat melindungi pesisir dari indukan nyamuk, karena nyamuk akan di mangsa oleh ikan dan hewan kecil lainnya yang hidup di ekosistem mangrove.

Beberapa responden mengetahui bahwa akar mangrove dapat menahan tanggul tambak dari hempasan ombak air laut, karena akarnya banyak, akarnya besar. Namun yang tidak setuju mengatakan alasan bahwa belum pernah melihat sendiri bagaimana akar mangrove menahan tanggul tambak. Adapun data secara lengkap dapat di lihat pada tabel 2.

Tabel 2. Tanggapan Masyarakat terhadap Manfaat Mangrove di Bidang Lingkungan

\begin{tabular}{|c|l|c|c|c|}
\hline No & \multicolumn{1}{|c|}{ Manfaat } & $\begin{array}{c}\text { Ya } \\
\mathbf{( \% )}\end{array}$ & $\begin{array}{c}\text { Tidak } \\
\mathbf{( \% )}\end{array}$ & $\begin{array}{c}\text { Jumlah } \\
\mathbf{( \% )}\end{array}$ \\
\hline 1 & Melindungi pesisir dari ombak. & 93,3 & 6,7 & 100 \\
\hline 2. & $\begin{array}{l}\text { Menahan abrasi air laut/ masuknya air } \\
\text { laut }\end{array}$ & 79,3 & 20,7 & 100 \\
\hline 3. & Membuat stabil kawasan pantai & 86,7 & 13,3 & 100 \\
\hline 4. & Melindungi pesisir dari tsunami & 86,7 & 13,3 & 100 \\
\hline
\end{tabular}




\begin{tabular}{|c|l|c|c|c|}
\hline 5. & $\begin{array}{l}\text { Tempat berlindung dan berkembang biak } \\
\text { unt flora, fauna (ikan, udang dll) }\end{array}$ & 96,7 & 3,3 & 100 \\
\hline 6. & $\begin{array}{l}\text { Menurunkan racun dari air sungai yang } \\
\text { tercemar }\end{array}$ & 56,7 & 43,3 & 100 \\
\hline 7. & Melindungi pesisir dari indukan nyamuk & 40 & 60 & 100 \\
\hline 8. & Penahan tanggul tambak & 83,3 & 16,7 & 100 \\
\hline
\end{tabular}

\section{Bidang Ekonomi}

Dibidang ekonomi, sebagian besar responden (96,7\%) mengetahui bahwa dengan adanya mangrove akan dapat memberikan manfaat dibidang perekonomian mereka dengan semakin banyaknya jenis ikan, udang, kepiting, ketam dll yang bersembunyi di sekitar akar mangrove sehingga dapat ditangkap dan dikonsumsi sendiri ataupun dijual sebagai tambahan pemasukan keuangan keluarga. Udang merupakan salah satu hasil dari ekosistem mangrove yang bernilai komersial tinggi.

Sebagaimana bapak S (49 thn) mengatakan bahwa :

"kalau banyak mangrove, bisa cari udang didekar akarnya, terus bisa di jual mb..."

Terdapat 36,7\% responden setuju untuk menggunakan mangrove sebagai kayu untuk membangun rumah, $86,7 \%$ responden setuju dapat sebagai kayu bakar, 36,7\% responden setuju penggunaan kayu mangrove sebagai arang, dan 33,3\% responden setuju kayu mangrove dapat dimanfaatkan sebagai perabot rumah tangga karena akarnya kuat, kayunya baik, namun yang tidak setuju mengatakan bahwa kayunya terlalu kecil dan pendek, tidak kuat dll sehingga tidak cocok untuk bahan membangun rumah, ataupun perabot rumah tangga.

Terdapat $40 \%$ responden yang mengetahui manfaat bahwa akar tanaman mangrove dapat digunakan untuk memberi warna kain. Namun sebagian besar responden (60\%) tidak mengerti manfaat tanin mangrove. Terdapat $20 \%$ responden yang setuju dengan ada bagian mangrove yang bisa dikonumsi yaitu buah dan $10 \%$ responden mengetahui bahwa ada bagian tanaman bakau yang dapat dimanfaatkan sebagai obat. Bapak Y (50 thn) mengatakan bahwa,: "buah tanaman mangrove dapat dimakan $\mathrm{mb}$, tapi saya tidak pernah makan..., bahkan ada yangbisa dibuat jamu diabetes.......". sebagaimana Bapak T (55 tahun) mengatakan bahwa “iya mb, buahnya bulat, bisa dimakan". Adapaun data tanggapan masyarakat terhadap manfaat mangrove dibidang ekonomi secara lengkap dapat dilihat pada tabel 3.

Tabel 3. Tanggapan Masyarakat terhadap Manfaat Mangrove di Bidang Ekonomi 


\begin{tabular}{|c|l|c|c|c|}
\hline No & \multicolumn{1}{|c|}{ Manfaat } & $\begin{array}{c}\text { Setuju } \\
\text { (\%) }\end{array}$ & $\begin{array}{c}\text { Tidak Setuju } \\
\text { (\%) }\end{array}$ & $\begin{array}{c}\text { Jumlah } \\
(\mathbf{1 0 0} \%)\end{array}$ \\
\hline 1. & $\begin{array}{l}\text { Banyak jenis ikan, udang,kepiting, } \\
\text { ketam dll di sekitar tumbuhan } \\
\text { mangrove, bakau/ kayu apu }\end{array}$ & 96,7 & 3,3 & 100 \\
\hline 2. & $\begin{array}{l}\text { Kayu mangrove dapat digunakan } \\
\text { untuk membangun rumah }\end{array}$ & 36,7 & 63,3 & 100 \\
\hline 3. & $\begin{array}{l}\text { Kayu mangrove dapat digunakan } \\
\text { untuk kayu bakar }\end{array}$ & 86,7 & 13,3 & 100 \\
\hline 4. & $\begin{array}{l}\text { Kayu mangrove dapat digunakan } \\
\text { untuk arang }\end{array}$ & 36,7 & 63,3 & 100 \\
\hline 5. & $\begin{array}{l}\text { Kayu mangrove dapat digunakan } \\
\text { untuk perabot rumah tangga }\end{array}$ & 33,3 & 66,7 & 100 \\
\hline 6. & $\begin{array}{l}\text { Tanin mangrove dapat digunakan } \\
\text { untuk mewarnai, untuk kain layar, } \\
\text { perekat, bahan plastik }\end{array}$ & 40 & 60 & 100 \\
\hline 7. & $\begin{array}{l}\text { Ada bagian mangrove dapat } \\
\text { dikonsumsi }\end{array}$ & 20 & 8 & 90 \\
\hline 8. & $\begin{array}{l}\text { Ada bag mangrove dapat dipakai } \\
\text { sebagai obat obatan }\end{array}$ & 10 & & \\
\hline
\end{tabular}

Manfaat mangrove dalam bidang ekonomi masih belum dimengerti sebagian besar responden. Salah satu potensi ekonomi tanaman mangrove adalah tanin. Sumber tanin dapat diperoleh dari jenis mangrove (Siregar, 2009). Tanin dapat digunakan sebagai perekat dan pengawet. Dalam industri kimia tanin dapat digunakan sebagai pengganti perekat sintetik seperti formaldehida. Dari penelitian poedjirahajoe (2011) menunjukkan bahwa mangrove dari daerah pantai utara jawa tengah memiliki ekstrak tanin yang tinggi.

\section{Tanggapan negatif}

Penilaian negatif reponden terhadap tumbuhan mangrove perlu mendapatkan perhatian bagi semua pihak dalam upaya pengembangan mangrove dan rehabilitasi pantai. Memberikan informasi yang benar, dapat meningkatkan kesadaran masyarakat terhadap pentingnya mangrove. Respon negatif masyarakat terhadap berkembangnya mangrove juga bervariasi. Terdapat $43,3 \%$ responden yang mengatakan bahwa mangrove akan mengganggu tempat bersandarnya perahu mereka, namun terdapat $56,7 \%$ responden yang sudah paham bahwa mangrove tidak mengganggu bersandarnya perahu jika ditanam ditempat yang benar. Sebagaimana bapak O (57 tahun) yang mengatakan bahwa:

“.....sebenarnya tidak akan mengganggu perahu jika lokasinya sendiri sendiri mb....".

Terdapat $86,7 \%$ responden menganggap mangrove itu indah dan tidak mengganggu pemandangan. Alasan yang dikemukakan adalah pantai jadi teduh, tampak lebih hijau dll.

Terdapat 23,3\% responden yang menganggap bahwa dengan adanya mangrove daerah menjadi terlihat seram dan angker. Hal ini disebabkan mereka beranggapan bahwa 
dengan adanya mangrove maka daerah akan terlihat gelap dan seram sehingga menakutkan. Terdapat 33,3\% responden yang setuju bahwa mangrove bisa menjadi tempat binatang buas yang berbahaya seperti ular. Namun beberapa responden beranggapan bahwa tidak akan menjadi tempat binatang buas, karena ramai dan banyak orang. Terdapat $23,3 \%$ responden yang menyatakan bahwa dengan adanya mangrove maka membuat pantai kotor atau terlihat kotor. Adapun data secara lengkap tentang persepsi negatif masyarakat terhadap mangrove dapat dilihat pada tabel 4.

Tanaman mangrove dapat berpotensi sebagai tempat wisata yang indah dan menyenangkan jika dikelola, diatur dan dipelihara dengan baik. Dengan adanya kawasan mangrove yang terkelola dengan baik maka dapat menjadi tujuan tempat wisata sehingga memberikan manfaat secara ekonomi sekaligus manfaat ekologis bagi lingkungan.

Tabel 4. Tanggapan Negatif Masyarakat terhadap Manfaat Mangrove

\begin{tabular}{|c|l|c|c|c|}
\hline No & \multicolumn{1}{|c|}{ Manfaat } & $\begin{array}{c}\text { Setuju } \\
(\%)\end{array}$ & $\begin{array}{c}\text { Tidak } \\
\text { Setuju } \\
(\%)\end{array}$ & $\begin{array}{c}\text { Jumlah } \\
(\mathbf{1 0 0} \%)\end{array}$ \\
\hline 1. & Mengganggu bersandarnya perahu & 43,3 & 56,7 & 100 \\
\hline 2. & Mengganggu pemandangan & 13,3 & 86,7 & 100 \\
\hline 3. & Membuat daerah terlihat angker & 23,3 & 76,7 & 100 \\
\hline 4. & Tempat binatang buas & 33,3 & 66,7 & 100 \\
\hline 5. & Mengotori & 23,3 & 76,7 & 100 \\
\hline
\end{tabular}

Sikap Negatif atau tanggapan negatif adalah sikap yang menunjukkan atau memperlihatkan penolakkan atau tidak menyetujui (Ahmad A, 1991:166). Tanggapan negatif dari beberapa responden sering kali terkait dengan kepercayaan dan budaya setempat. Budaya didefinisikan sebagai tatanan pengetahuan, pengalaman, kepercayaan, nilai, sikap, makna, hirarki, agama, waktu, peranan, hubungan ruang, konsep alam semesta, objek-objek materi dan milik yang diperoleh sekelompok besar orang dari generasi ke generasi melalui usaha individu dan kelompok (Mulyana dan Rakmat, 2002 : 18). Masyarakat percaya bahwa jika tidak sedang melaut maka kapal harus masuk ke sungai. Sehingga seringkali mangrove ditebang untuk dijadikan tempat bersandar perahu.

\section{Perilaku}

Dilakukan wawancara dengan responden terkait perilaku mereka terkait dengan keberadaan mangrove. Terdapat 93,3\% responden mangaku tidak pernah sama sekali menanam mangrove atau bakau, dengan alasan tidak ada bibitnya, sibuk bekerja dll. sedangkan terdapat $6,7 \%$ responden yang mengaku pernah menanam mangrove. Responden yang mengaku pernah menanam mangrove sebagian besar adalah responden yang berusia lanjut, oleh karena mereka mengaku pernah 
merasakan manfaat adanya mangrove seperti menangkap udang dan ikan dengan mudah di bawah akar mangrove.

Dari keseluruhan responden, terdapat $76,7 \%$ responden yang pernah menebang mangrove. Mereka beralasan menebang mangrove untuk menempatkan perahu mereka ketika tidak berlayar. Hanya $10 \%$ responden yang mengaku pernah membiakkan mangrove, yaitu dengan membiarkan ataupun dengan membiakkan mangrove dengan menanam batang mangrove.

Terdapat $13,3 \%$ responden yang mengaku pernah membakar pohon mangrove. Pembakaran mangrove disekitar pantai disebabkan mangrove dianggap mengganggu tempat bersandarnya perahu. Dari responden yang diwawancara, terdapat $93,3 \%$ responden yang mengaku tidak pernah memanfaatkan tumbuhan mangrove untuk peningkatan perekonomian. Hal ini disebabkan karena saat ini tumbuhan mangrove yang ada di pantai puger sangat sedikit, hampir tidak ada. Tidak menjauh terhadap tumbuhan mangrove karena dianggap angker dilakukan oleh 93,3\% responden. Adapun data secara lengkap dapat dilihat pada tabel 5.

Tabel 5. Perilaku Masyarakat terhadap Manfaat Mangrove di Bidang Ekonomi

\begin{tabular}{|l|l|l|l|l|}
\hline No & \multicolumn{1}{|c|}{ Manfaat } & $\begin{array}{c}\text { Pernah } \\
\mathbf{( 1 0 0 \% )}\end{array}$ & $\begin{array}{c}\text { Tidak } \\
\text { Pernah } \\
(\mathbf{1 0 0 \% )}\end{array}$ & \multicolumn{1}{|c|}{$\begin{array}{c}\text { Jumlah } \\
\mathbf{( 1 0 0 \% )}\end{array}$} \\
\hline 1. & Menanam mangrove/ bakau/ kayu apu & 6,7 & 93,3 & 100 \\
\hline 2. & Menebang mangrove/ bakau/ kayu apu & 23,3 & 76,7 & 100 \\
\hline 3. & $\begin{array}{l}\text { Membiakkan/ melestarikan mangrove/ } \\
\text { bakau/ kayu apu }\end{array}$ & 10 & 90 & 100 \\
\hline 4 & Membakar mangrove/ bakau/ kayu apu & 13,3 & 86,7 & 100 \\
\hline 5. & $\begin{array}{l}\text { Memanfaatkan keberadaan mangrove } \\
\text { bagi peningkatan ekonomi }\end{array}$ & 6,7 & 93,3 & 100 \\
\hline 6. & Menjauh krn dianggap angker & 6,7 & 93,3 & 100 \\
\hline
\end{tabular}

\section{Tingkat Partisipasi Masyarakat terhadap Pengembangan Mangrove}

Setelah mengetahui tanggapan, sikap dan perilaku responden yang berhubungan dengan pengembangan mangrove, kemudian dilakukan wawancara terhadap kesedian masyarakat. Apakah mereka bersedia atau mau ikut berpartisipasi terhadap pengembangan mangrove di pesisir pantai puger. Dan ternyata antusiasme masyarakat terhadap partisipasi pengembangan mangrove dipesisir puger cukup baik. Terdapat 93,3\% responden menyatakan mau ikut berpartisipasi dalam pengembangan mangrove dipesisir puger. Hanya terdapat 6,7\% responden yang tidak bersedia untuk ikut berpartisipasi dalam pengembangan mangrove. Mereka beralasan tidak ada waktu karena repot dan sibuk bekerja mencari nafkah.

Tingkat partisipasi masyarakat dalam pengembangan mangrove akan meningkat sebanding dengan peningkatan ekonomi yang dapat dirasakan oleh masyarakat. jika masyarakat merasakan dampak langsung secara ekonomi dengan keberadaan mangrove, maka bisa dipastikan tingkat 
partisipasi masyarakat dalam pengembangan mangrove juga akan meningkat. Peningkatan perkonomian masyarakat dengan pengembangan mangrove, salah satunya adalah dengan pengembangan pariwisata mangrove (Ekowisata), namun demikian sebelum dilakukan pengembangan mangrove sebagai ekowisata daerah perlu dilakukan studi Kelayakan aspek pemasaran, teknis, keuangan, lingkungan dan sosial dalam mengembangkan kawasan mangrove untuk ekowisata harus diidentifikasi secara jelas sebelum dikembangkan dan dioperasikan (Wardhani, KM. 2011)

Data tingkat partisipasi masyarakat secara lengkap dapat dilihat pada tabel 6.

Tabel 6. Tingkat Partisipasi Masyarakat terhadap Pengembangan Mangrove

\begin{tabular}{|c|l|c|c|}
\hline No & \multicolumn{1}{|c|}{ Umur } & Jumlah & Prosentasi \\
\hline 1. & $\begin{array}{l}\text { Ikut berpartisipasi dalam } \\
\text { pengembangan } \\
\text { mangrove }\end{array}$ & 28 & 93,3 \\
\hline 2. & $\begin{array}{l}\text { Tidak Ikut berpartisipasi } \\
\text { dalam pengembangan } \\
\text { mangrove }\end{array}$ & 2 & 6,7 \\
\hline & \multicolumn{1}{|c|}{ Total } & 30 & 100 \\
\hline
\end{tabular}

\section{Kendala dan Permasalahan Pengembangan Mangrove di Pesisir Puger}

Dari hasil pengamatan dan wawancara masyarakat sekitar dilapangan, luas mangrove, bakau, kayu gabus di pesisir puger terutama sekitar puger wetan sudah sangat sedikit. Hal ini berbeda dengan kondisi tahun 80 an dimana tanaman mangrove sejenis krangkongan, pandan laut, kayu tanjang, tumbuhan mangrove yg berdaun bulat, tumbuhan mangrove daun lonjong masih banyak ditemukan dipesisir puger. Dari hasil pengamatan dan wawancara responden, diketahui terdapat beberapa kendala atau permasalahan pengembangan mangrove dipesisir puger, yaitu antara lain :

Pendataran perahu. Masyarakat setempat memiliki keyakinan bahwa perahu jika tidak sedang dipakai melaut harus dinaikkan. Tidak boleh berada di tempat yang terkena air laut. Dengan demikian maka masyarakat melakukan penebangan tanaman mangrove untuk kemudian digunakan sebagai tempat tambatan perahu. Dengan adanya pendaratan perahu ditempat hidup tanaman mangrove, seringnya mangrove terkena geseran dan tinjakan dari perahu yang mendarat akan membuat perkembangan mangrove terganggu dan bahkan rusak.

Sampah. Penduduk masih sulit untuk menjaga kebersihan lingkungan, dimana masyarakat seringkali tidak membuang sampah pada tempatnya tetapi membuang sampah ke sungai yang kemudian ke laut. Tumpukan sampah di pesisir menyebabkan tumbuhan mangrove tidak dapat tumbuh dengan optimal. Sampah sampah tersebut dapat menempel pada tumbuhan mangrove. Dari identifikasi dan wawancara masyarakat sekitar banyak yang beternak sapi disepanjang sungai yang menuju ke laut karena mudah untuk membuang kotoran ternak langsung ke sungai.

Keterbatasan Bibit Mangrove. Bibit mangrove dibutuhkan untuk pengembangan mangrove dipesisir puger. Pengadaan bibit mangrove diwilayah jember masih cukup sulit sehingga dibutuhkan pengadaan bibit mangrove dari tempat lain yang cocok jika ditanam di pesisir puger, seperti sejenis 
krangkong, pandan laut (nypa fruticans), kayu tanjang (rhizopora stylosa), maupun jenis mangrove yang berdaun bulat (sonneratia caseolaaris) dan lonjong (lumnitcera racemosa).

\section{KESIMPULAN DAN SARAN}

Adapun kesimpulan dalam penelitian ini adalah :

Karakteristik responden sebagian besar berusia 40-49 tahun, tingkat pendidikan rendah, tingkat pendapatan rendah. Tanggapan masyarakat terkait pengembangan mangrov adalah positif, baik dari sisi lingkungan maupun dari sisi ekonomi.Masih terdapat tanggapan masyarakat yang negatif terkait pengembangan mangrove, karena kurangnya pengetahuan terkait manfaat mangrove. Perilaku masyarakat cukup baik dalam pengembangan mangrove. Tingkat partisipasi masyarakat dalam pengembangan mangrove cukup baik.

Perlu dilakukan peningkatan pengetahuan terhadap kegunaan mangrove pada masyarakat puger, baik manfaatnya terhadap lingkungan dan ekonomi oleh institusi terkait seperti Universitas Jember, dinas perikanan dan kelautan supaya tidak ada tanggapan negatif terhadap keberadaan mangrove serta dapat meningkatkan partisipasi masyarakat dalam pengembangan mangrove di pesisir pantai puger. Dari beberapa kendala atau permasalahan pengembangan mangrove dipesisir puger, maka ada beberapa teknik dan solusi untuk pengembangan mangrove di pesisir puger antara lain :

1. Pembagian pendaratan perahu. Dilakukan pembagian wilayah pendaratan perahu di pantai masing masing desa, hal ini untuk menghindari pendaratan perahu disembarang tempat.

2. Pengelolaan sampah terpadu. Perlu dilakukan upaya pengelolaan sampah terpadu oleh dinas terkait untuk meminimalkan cemaran sampah yang masuk ke pesisir dan pantai sehingga tidak mengganggu tumbuh kembang tanaman mangrove.

3. Penyediaan bibit mangrove. Adanya penyediaan bibit mangrove di daerah jember akan sangat menunjang bagi pengembangan mangrove, termasuk pengembangan mangrove di pesisir puger. Penetapan Lokalisasi daerah konservasi mangrove di pesisir puger oleh pemerintah dan masyarakat.

\section{DAFTAR PUSTAKA}

Ahmadi A, 1991, Psikologi sosial, Jakarta, Renika Cipta Pakpahan HT, Richard W. E. Lumintang, dan Djoko Susanto, 2006. Hubungan Motivasi Kerja Dengan Perilaku Nelayan Pada 
Usaha Perikanan Tangkap. Jurnal Penyuluhan. Maret 2006,Vol. 2, No. 1. 18582664. Institut Pertanian Bogor.

Effendi O.W , 2006, Ilmu Komunikasi Teori dan Praktek, Bandung, PT. Remaja Rosdakarya.

Krauss K W, C E Lovelock, K L McKee, L Hoffman, S M L Ewe, P Sousa. 2008.

Environmental Ddrivers in Mangrove Establishment and Early Development: A Review. Journal Aquatic Botany 89: 105-127.

Mulyana, Dedy \& Rahmat, Jalaludin. 2002. Komunikasi Antarbudaya: Panduan Berkomunikasi dengan Orang-orang yang Berbeda Budaya. Bandung: PT. Remaja Rosdakarya.

Prihandoko, dkk. 2012. Faktor-Faktor yang Mempengaruhi Perilaku Nelayan Artisanal dalam Pemanfaatan Sumberdaya Perikanan di Pantai Utara Provinsi Jawa Barat. Jurnal Penyuluhan, September 2012 Vol. 8 No. $2.2 \mathrm{http}$ :download.portalgaruda.org/article.php?article=268140\&val...

Purwati, BD dan kusuma W. 2013. Gaya Hidup Msyarakat Nelayan. http://repository.unej.ac.id/handle/123456789/58743

Primyastanto, Ratih PD, Edi S. 2010. Perilaku perusakan Lingkungan Masyarakat Pesisir dalam Perspektif Islam (Studi Kasus pada Nelayan dan Pedagang Ikan di Kawasan Pantai, Tambak desa Tambak rejo, kecamatan Wonotirto, Kabupaten Blitas Jawa Timur). Jurnal Universitas Brawijaya. Vol 1, No 1 (2010) Universitas Brawijaya. http://jpal.ub.ac.id/index.php/jpal/article/view/99

Poedjirahajoe E, Ragil widyorini, Ni putu diana M. 2011. Kajian Ekosistem Mangrove Hasil Rehabilitasi pada Berbagai Tahun Tanam untuk Estimasi Kandungan Ekstrak Tanin di Pantai Utara Jawa Tengah. Jurnal Ilmu Kehutanan. Vol. V. No. 2. Juli- September 2011.

Siregar UCR. 2009. Kualitas Perekat Tanin dari Beberapa Kulit Kayu Mangrove. Fakultas Kehutanan Universitas Sumatra Utara. Medan.

Wardhani KM, 2011. Kawasan Konservasi Mangrove: Suatu Potensi Ekowisata. Jurnal KELAUTAN, Volume 4, No.1 April 2011 ISSN : 1907-9931. journal.trunojoyo.ac.id/jurnalkelautan/article/viewFile/891/784

WJS Poerwodarminto. 1983. Kamus Umum Bahasa Indonesia, 1983, Pembinaan dan Pusat Pengembangan Bahasa, Jakarta, Balai Pustaka 